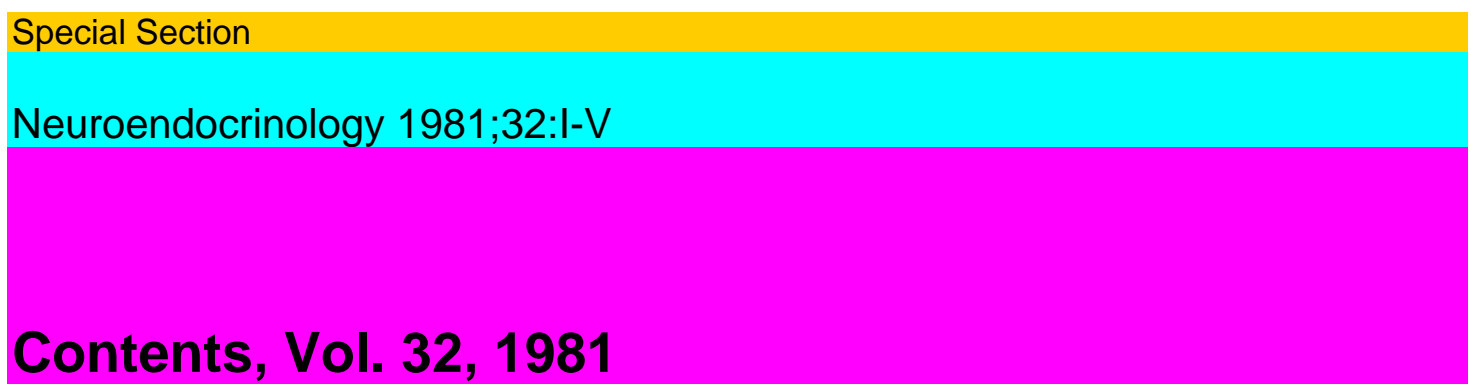

Editor-in-Chief:

W.F. Ganong, San Francisco, Calif.

Associate Editors:

D.J. Ramsay, San Francisco, Calif. LA. Reid, San Francisco, Calif. R.I. Weiner, San Francisco, Calif.

\title{
Editorial Board:
}

A. Arimura, New Orleans, La.

G.M. Besser, London

K. Brown-Grant, St. John's, Nfld. M.J. Brownstein, Bethesda, Md. B.A. Cross, Babraham J.D. Fernstrom,

Cambridge, Mass. J.T. Fitzsimons, Cambridge H.G. Friesen, Winnipeg, Man.

B. Halász, Budapest

J. Hayward, Chapel Hill, N.C.

\author{
T. Hiroshige, Sapporo \\ D. Jacobowitz, Bethesda, Md. \\ C. Kordon, Paris \\ B. McEwen, New York, N.Y. \\ B. Meyerson, Uppsala \\ R.Y. Moore, Stony Brook, N.Y. \\ R.L. Moss, Dallas, Tex. \\ J.D. Neill, Birmingham, Ala. \\ M. Palkovits, Budapest \\ J.L. Pasteels, Brussels
}

V.D. Ramirez, Urbana, III. R.J. Reiter, San Antonio, Tex. L.P. Renaud, Montreal, Que. K.B.Ruf, Montreal, Que. W.H. Sawyer, New York, N.Y. A. Tixier-Vidal, Paris W.W. Vale, San Diego, Calif. G.R. Van Loon, Toronto, Ont. W.O. Wuttke, Göttingen S.S.C. Yen, San Diego, Calif. 


\title{
S. Karger $\cdot$ Basel $\cdot$ München $\cdot$ Paris $\cdot$ London $\cdot$ New York $\cdot$ Sydney
}

Drug Dosage

The author and publisher have exerted every effort to ensure that drug selection and dosage set forth in this text are in accord with current recommendations and practice at the time of publication. However, in view of ongoing research, changes in government regulations, and the constant flow of information relating to drug therapy and drug reactions, the reader is urged to check the package insert for each drug for any change in indications and dosage and for added warnings and precautions. This is particularly important when the recommended agent is a new and/or infrequently employed drug.

All rights reserved.

No part of this publication may be translated into other languages, reproduced or utilized in any form or by any means, electronic or mechanical, including photocopying, recording, microco-pying, or by any information storage and retrieval system, without permission in writing from the publisher.

\author{
S. Karger AG, P.O.Box, Ch-4009 Basel \\ (Switzerland) \\ Printed in Switzerland by Genossenschaftsdruckerei Zurich \\ (gdz)
}

\section{Contents Vol. 32, 1981}

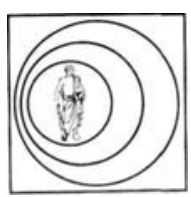

\section{No. 1, January}

Original Papers

Influence of Corticosterone on the Response to Gonadotropin-Releasing Hormone in Rats

Cohen, I.R.; Mann, D.R

Lack of Correlation between Hypothalamic Serotonin and the Ether-Induced ACTH Secretion in Adrenalectomized

Rats

Karteszi, M.; Palkovits, M.; Kiss, J.Z.; Kanyicska, B.;

Fekete, M.I.K.; Stark, E

Increased LH Secretory Response to LHRH After Hypophy-

seal Stalk-Transection of Monkeys

Frawley, L.S.; Dailey, R.A.; Tindall, G.T.; Neill, J.D

Development of Circadian Rhythms in Serum Hormone Levels in the Immature Female Rat

Kimura, F.; Okano, H.; Kawakami, M 19

Biochemical Indices of Catecholaminergic Neuronal Activity

in the Median Eminence during the Estrous Cycle of the

Rat

Demarest, K.T.; Johnston, C. A.; Moore, K.E

Calcium-Dependent Changes in Electrical Properties of Pro-

lactin-Secreting Anterior Pituitary (2B8) Clonal Cells

Maruyama, T.; Shiino, M.; Rennels, E.G

Muscarinic Receptors in the Posterior Pituitary Gland

Tolliver, J.M.; Taylor, R.L.; Burt, D.R.

Degree of Inhibition of ACTH Release by Glucocorticoids in

Adrenalectomized Rats

Skakura, M.; Yoshioka, M.; Kobayashi, M.; Takebe, K. .. 38 Dopamine: Effects on Prolactin and Luteinizing Hormone Secretion in Ovariectomized Rhesus Macaques after Tran-

section of the Pituitary Stalk

Pavasuthipaisit, K.; Hess, D.L.; Norman, R.L.; Adams,

T.E.; Baughman, W.L.; Spies, H.G

Intralimbic Progesterone and Methysergide Facilitate Lordot-

ic Behavior in Estrogen-Primed Female Rats

Franck, J.A.E.; Ward, I.L

Progress in Neuroendocrinology 
The Sites of Action of Ovarian Steroids in the Regulation of LH Secretion

Goodman, R.L.; Knobil, E

Announcements.

\section{No. 2, February}

Original Papers

Central Catecholamine Depletion: Effects on Physiological

Growth Hormone and Prolactin Secretion

Willoughby, J.O.; Day, T. A

Pituitary Function in the Empty Sella Syndrome

Brismar, K.; Efendic, S

Development of Pulsatile LH Release as a Function of Time

Following Ovariectomy in the Rat

Weick, R.F.; Soper, B.D.; Greenberg, D 
(D-Met ${ }^{2}$, Pro $^{5}$ )-Enkephalinamide-Induced Blockade of Ovu-

lation and its Reversal by Nalaxone in the Rat

Köves, K.; Marton, J.; Molnár, J.; Halász, B.

Vasopressin and CRF-ACTH in Adrenalectomized and Dexamethasone-Treated Rats

Hashimoto, K.; Yunoki, S.; Kageyama, J.; Ohno, N.; Ta-

kahara, J.; Ofuji, T.

The Dexamethasone Suppression Test as a Measure of Hypo-thalamic-Pituitary Feedback Sensitivity and its Relationship to Behavioral Arousal

Kalin, N.H.; Cohen, R.M.; Kraemer, G.W.; Risch, S.C.; Shelton, S.; Cohen, M.; McKinney, W.T.; Murphy, D. L... 92

Attempts to Demonstrate Peptide Localization and Secretion

in Primary Cell Cultures of Fetal Rat Hypothalamus

Denizeau, F.; Dubé, D.; Antakly, T.; Lemay, A.; Parent,

A.; Pelletier, G; Labrie, F ..................................................... 96

Sodium-Dependent Interaction of Benzamides with Dopamine Receptors in the Rat and Dog Anterior Pituitary Glands

Stefanini, E.; Clement-Cormier, Y.; Vernaleone, F.; Devo-

to, P.; Marchisio, A.M.; Collu, R .

Sexual Differences in Tuberoinfundibular Dopamine Nerve

Activity Induced by Neonatal Androgen Exposure

Demarest, K.T.; McKay, D.W.; Riegle, G.D.; Moore,

K.E ........................................................................... 108

Interaction of Age and Thyroid Hormone Status on Beta-En-

dorphin Content in Rat Corpus Striatum and Hypothala

mus

Gambert, S.R

Progress in Neuroendocrinology

Serotonergic Stimulation of Pituitary-Adrenocortical Func

tion in Rats

Fuller, R.W

Announcement

\section{No. 3, March}

\section{Original Papers}

\section{Adrenal}

Neurosecretory

Rat.

ticosterone

Silverman,

Zimmermann, E.A

Steroid
System

Differential

$$
\text { A.J.; }
$$

Effect of Electrical Stimulation of the Dorsomedial Hypotha

lamic Nucleus on Pulsatile LH Release in Ovariectomized

Rats

Gallo, R.V .....

Adenohypophysis Has an Inherent Property for Pulsatile Pro lactin Secretion

Shin, S.H.; Reifel, C.W
Inhibition

to the

Effects

Administration

Hoffman,

D.; 134 139 
GABA and Muscimol Inhibit the Release of Prolactin from Dispersed Rat Anterior Pituitary Cells

Grossman, A.; Delitala, G.; Yeo, T.; Besser, G.M

Regulation of Prolactin Secretion in Patients with Cushing's

Disease. A Comparative Study on the Effects of Dexamethasone, Lysine Vasopressin and ACTH on Prolactin Secretion by the Rat Pituitary Gland in vitro

Lamberts, S.W.J.; Quijada, M. de; Visser, T.J

Ionic Channels Involved in the LHRH and SRIF Release

from Rat Mediobasal Hypothalamus

Drouva, S.V.; Epelbaum, J.; Hery, M.; Tapia-Arancibia,

L.; Laplante, E.; Kordon, C.

Opiate Receptors Modulate LHRH and SRIF Release from

Mediobasal Hypothalamic Neurons

Drouva, S.V.; Epelbaum, J.; Tapia-Arancibia, L.; La

plante, E.; Kordon, C...

Experimental Studies on the Development of Sex Differences

in the Release of Dopamine from Striatal Tissue Frag

ments in vitro

Becker, J.B.; Ramirez, V.D

The Site of Inhibitory Action of a Natural (Corticosterone) and Synthetic Steroid (Dexamethasone) in the Hypothala-mus-PituitaryAdrenal Axis Sakakura, M.; Yoshioka, M.; Kobayashi, M.; Takebe, K. . 174

Immunohistochemical Demonstration of LHRH Neurons

and Their Pathways in the Rat Hypothalamus

Kawano, H.; Daikoku, S.

Further Studies on Dopamine-Induced Suppression of Pulsa

tile LH Release in Ovariectomized Rats

Gallo, R.V

Announcement

\section{No. 4, April}

\section{Original Papers}

Daily Rhythms in Cortisol and Melatonin in Primate Cere-brospinal Fluid. Effects of Constant Light and Dark Perlow, M.J.; Reppert, S.M.; Boyar †, R.M.; Klein, D.C... 193

Hypothalamic Catecholamine Levels in Dogs with Spontaneous Hyperadrenocorticism

Meijer, J.C.; Croughs, R.J.M.; Rijnberk, A.; Versteeg,

D.H.G.; Ree, J.M. van

In situ Estradiol and Progestin (R5O2O) Localization in the Vascularly Separated and Isolated Hypothalamus of the Rhesus Monkey Garris, D.R.; Billiar, R.B.; Takaoka, Y.; White, R.J.;

Little, B 202

Characterisation of the Pro Opiocortin Family of Peptides in Human Cerebrospinal Fluid

McLoughlin, L.; Lowry, P.J.; Ratter, S.J.; Hope, J.; Besser,

G.M.; Rees, L.H. 209

Central Nervous System and Pituitary Mechanisms in Dop-aminergic Stimulation of Growth Hormone Release in Women Ferrari, C; Caldara, R.; Barbieri, C; Testori, G.P.; Benco,

R.;Trezzi, R.;Crossignani, R.M.; Rampini, P 213

Multiunit Activity in the Anterior Median Eminence and Ad- 
jacent Areas of the Hypothalamus of the Ewe in Relation to LH Secretion

Thiéry, J.C.; Pelletier, J

Catecholestrogens and Induction of Sexual Behavior in the

Ovariectomized Rat

Naish, S.J.; Ball, P.

Dopamine Levels in Hypophysial Stalk Plasma and Prolactin

Levels in Peripheral Plasma of the Lactating Rat: Effects

of a Simulated Suckling Stimulus

Greef, W.J. de; Plotsky, P.M.; Neill, J.D.

Effect of Neonatal Intrahypothalamic Testosterone Implants on Cyclicity and Adult Sexual Behavior in the Female Hamster Hamilton, M.A.; Vomachka, A.J.; Lisk, R.D.; Gorski,

Effects of Lesions in the Medial Basal Part of the Suprachi-

asmatic Area on Prolactin and Gonadotropin Surges In

duced by Estrogen and Progesterone Treatment in Ova

riectomized Rats

Kawakami, M.; Arita, J

Progress in Neuroendocrinology

The Circumventricular Organs and the Central Actions of

Angiotensin

Simpson, J.B

Announcements.

\section{No. 5, May}

\section{Original Papers}

Comparison of Brainstem and Adrenal Circadian Patterns of Epinephrine Synthesis

Turner, B.B.; Wilens, T.E.; Schroeder, K.A.; Katz, R.J.;

Carroll, B.J 257

Persistence of Circadian Rhythms of Melatonin and N-Ace-

tylserotonin in the Serum of Rats after Pinealectomy

Yu, H.S.; Pang, S.F.; Tang, P.L.; Brown, G.M ...

Photoperiodic Control of Reproduction in Olfactory-Bulb-

ectomized Rats

Nelson, R.J.; Zucker, 1 .

Impact of Social Conflict between Mice on Testosterone

Binding in the Central Nervous System

Raab, A.; Haedenkamp, G.

Effect of Partial Deafferentation of the Hypothalamus on

Stress-Induced LH Suppression and Prolactin Release

Kawakami, M.; Higuchi, T.

Immunocytological Determination of Gonadotropic and Thyrotropic Cells in Fetal Rat Anterior Pituitary during Normal Development and under Experimental Conditions Begeot, M.; Dupouy, J.P.; Dubois, M.P.; Dubois, P.M. ... 285

Studies on Muscarinic Receptors in Mouse and Rat Hypotha

lamus: A Comparison of Sex and Cyclical Differences

Avissar, S.; Egozi, Y.; Sokolovsky, M

Biochemical Characterization and Sex Dimorphism of Mus

carinic Receptors in Rat Adenohypophysis

Avissar, S.; Egozi, Y.; Sokolovsky, M 
Preparation of ${ }^{3} \mathrm{H}-\left[3-\mathrm{Me}-\mathrm{His}^{2}\right] \mathrm{TRH}$ as an Improved Ligand for TRH Receptors

Taylor, R.L.; Burt, D.R .

Announcement .....

\section{No. 6, June}

Original Papers

Pathways by which Stimuli Originating in the Cingulate Cor tex Inhibiting LH Secretion Reach the Hypothalamus

Cáceres, A.; Taleisnik, S

Correlative Changes in the Response to Castration and the

Onset of Refractoriness in Male Golden Hamsters

Tate-Ostroff, B.; Stetson, M.H.

Amygdalectomy Inhibits Adrenocortical Responses to Somatosensory and Olfactory Stimulation

Feldman, S.; Conforti, N

The Origin of Cerebrospinal Fluid Somatostatin: Hypotha-

lamic or Disperse Central Nervous System Secretion?

Sørensen, K.V.; Christensen, S.E.; Hansen, A.P.; Ingers-

lev, J.; Pedersen, E.; Ørskov, H. 
Pituitary Hollow Fiber Units in vivo and in vitro

Hymer, W.C.; Wilbur, D.L.; Page, R.; Hibbard, E.; Kel-

sey, R.C.; Hatfield, J.M.

Pituitary Hollow Fiber Units in the Dwarf Mouse

Hymer, W.C.; Harkness, J.; Bartke, A.; Wilbur, D.; Hat-

field, J.M.; Page, R.; Hibbard, E

In situ Subcellular Distribution and Metabolism of Progesterone, Estradiol and Androstenedione in the Vascularly Separated and Isolated Hypothalamus of the Female Rhesus Monkey

Billiar, R.B.; Takaoka, Y.; Johnson, W.; White, R.J.; Lit

tle, $\mathrm{B}$

Relationship between Rhythmic Motor Activity and Plasma

Luteinizing Hormone in Ovariectomized Sheep

Rasmussen, D.D.; Malven, P.V.

Stimulation of Prolactin Secretion by Neuroleptics in Rats

with Medial Basal Hypothalamic Lesions

Cheung, C.Y.; Neill, A.C.; Weiner, R.I.

Author Index

375

Subject Index 